\title{
Integrated remote sensing and GIS techniques to delineate groundwater potential area of Chamchamal basin, Sulaymaniyah, NE Iraq
}

\author{
Diary A.Mohammed Al-Manmi ${ }^{1 *}$, Sarkhel H. Mohammed ${ }^{1}$, Péter Szücs ${ }^{2}$ \\ ${ }^{\prime}$ Dept. of Geology, College of Science, University of Sulaimani, Kurdistan, Iraq \\ ${ }^{2}$ Institute of Environmental Management, Faculty of Earth Science and Engineering, University \\ of Miskolc, Hungary \\ Corresponding author: diary.amin@univsul.edu.iq
}

\begin{abstract}
Groundwater management in the semi-arid areas is a crucial issue and requires more scientific study and techniques. Groundwater potential areas for part of the Chamchamal basin are determined using two techniques, the analytical hierarchy process (AHP) and a geographic information system (GIS). Several Input factors were used to produce a thematic map, including geology, structure, drainage density, land-use/landcover, slope steepness, lineament density, and hydrogeology. Based on the relative importance, the layers are ranked which control the groundwater potential areas. The factor classified into several zones builds upon the hydrogeological characteristics and the classes weighted based on the relative standing to the potential area of groundwater. The output of the analysis showed that there are four zones of groundwater potential, good, moderate, poor, and very poor. The zones cover 10.4, 38.7, 43.93, and $6.96 \%$ of the area, respectively. Furthermore, the results showed that the southwest part of the area is the most favorable area for groundwater existence. While the center and some parts of the northeast characterized by low groundwater potential zones. To verify the final potential zones, the yield rates of 38 wells are used. The verification process verified that the categories of groundwater potential areas are closed to the results obtained from (AHP) and (GIS).
\end{abstract}

Keywords: GIS; groundwater management; Kurdistan; potential mapping; AHP.

\section{Introduction}

Nowadays, the management of groundwater resources has become an interesting topic globally because it is considered an exciting source for all living bodies. Certainly, sustainability, water quality, and quantity are the main issues among ordinary resources. Chamchamal basin is selected for this research because hydrogeological studies in the mentioned area are very rare and limited due to the enormous shortage of water demand. The water resources in the semi-arid the area like Chamchamal is under increasing pressure as the facility is extended to the population growth and has reached more than 175000 per capita. However, there is a good groundwater resource located in Bani Maqan province that can be used for agricultural activities and some other projects as well. The most important water supplies in the Chamchamal area are wells and groundwater resources. It is reported that domestic water covers between 50- 60\% of the region. Over the past few years, the Kurdistan regional government (KRG) from Dukan Lake has implemented a water supply project to minimize the water shortage in Chamchamal. The interesting study area located in Kurdistan region NE of Iraq, about $60 \mathrm{Km}$ to the NW of Sulaymaniyah City, between the longitudes $34^{\circ} 15^{\prime} 00^{\prime \prime}, 35^{\circ} 50^{\prime} 00^{\prime \prime}$ $\mathrm{N}$, and latitudes $\left(44^{\circ} 40^{\prime} 00^{\prime \prime}, 45^{\circ} 10^{\prime} 00^{\prime \prime}\right) \mathrm{E}$, which lies in zone $38 \mathrm{~N}$. The total area of the study catchment is $533 \mathrm{Km} 2$; the map of the study area is presented in (Figure 1). During winter, the Chamchamal area is characterized by heavy torrential rainfall with an annual rainfall range of $405 \mathrm{~mm}$, and the maximum rainfall that occurred in January is rated 
about $99 \mathrm{~mm}$. The average temperature ranges between $7-33.3{ }^{\circ} \mathrm{C}$. While in the summer season, the region is very hot, and the temperature ranges between $30-55^{\circ} \mathrm{C}$. Chamchamal region appears to be poor, the major activities being agronomy (wheat, barley, chickpeas, lentils, vegetables) and animal farming (sheep, goats, cattle) .

The existence of groundwater in any geographical area plays an important role in human life and their daily activities since the surface water is not quite enough to meet their demand. The quality of surface water differs from groundwater; appropriate management and exploitation of groundwater are needed in areas where groundwater resource is the main water supply. This study aims to find and assess the groundwater potential areas in Chamchamal district in the direction of groundwater and water policy sustainability. By using remote sensing and GIS techniques along with the hierarchical analytical process (AHP) method. Several geologic and hydrogeological conditions control the occurrence of groundwater, and from this point of view, this term is defined as the possibility of groundwater occurrence in an area (Al- Abadi, 2011).

The term "Groundwater potential" means the possible occurrence of groundwater resources (Jha et al., 2010). There are various direct and indirect methods for evaluating the potential area of groundwater (Agarwal \& Garg, 2016). Remote sensing, satellite data, and GIS platform are indirect methods, whereas conducting a geophysical study is one of the indirect methods. (Wattanasen \& Elming, 2008).

Many types of research have been conducted to investigate the effectiveness of GIS and remote sensing techniques in detecting the possible occurrence of groundwater. (Minor et al., 1994) have investigated the location of groundwater potential using remote sensing and GIS techniques. They developed a unique methodology that included combining multiple data to recognize groundwater and finding water wells. (Saraf \& Choudhury, 1998; Fashae et al., 2014), stated that the
GIS method is a powerful tool for combining and analyzing many thematic layers in delineating groundwater potential areas. (Krishnamurthy et al., 1996) showed the capability of remote sensing and GIS techniques for delineating groundwater potential zones. Moreover, some researchers like (Oh et al., 2011; Venkateswaran et al., 2014; Al-Manmi \& Rauf, 2016; Mogaji et al., 2016; Al- Abadi et al., 2016; Mohammed, 2017; Islami et al., 2018) have successfully integrated GIS, and remote sensing approaches for groundwater potential mapping studies.

The hierarchical analytical process (AHP) method is one of the commonly/broadly used Multiple criteria decision analysis (MCDA) models, which has also been used for environmental management schemes (Chandio et al., 2013). In this method, experts can note the relative importance of thematic layers to evaluate groundwater potential (Kaliraj et al., 2014; Al-Abadi \& Al-Shamma'a, 2014). (Hajkowicz \& Collins, 2007) examined the application of the MCDA methods in water resource management and showed that the AHP is widely used in this area. Recently (Panahi et al., 2017) and (Mohammadi-Behzad et al., 2018) studied the delineation of groundwater potential zones using remote sensing, GIS, and AHP technique in Iran. Overall, the conclusions of their research revealed that the utilized methodology is not only a helpful framework for the fast evaluation of groundwater potential but also recommended being used in other areas, particularly with insufficient accessible data.

The potential of groundwater can be affected by different factors like similar lithology forming different geomorphic and geometric units and vice versa. Moreover, many surface factors and features play an important role in the recharge of groundwater, such as topography, geomorphology, drainage pattern and density, and depressions which cause in the forms of surface water bodies, etc. The Generation of potential groundwater models for a specific area depends on identifying, evaluating, and quantifying the mentioned features $(2011 ; \&$ Al-Shamma'a, 2014). 


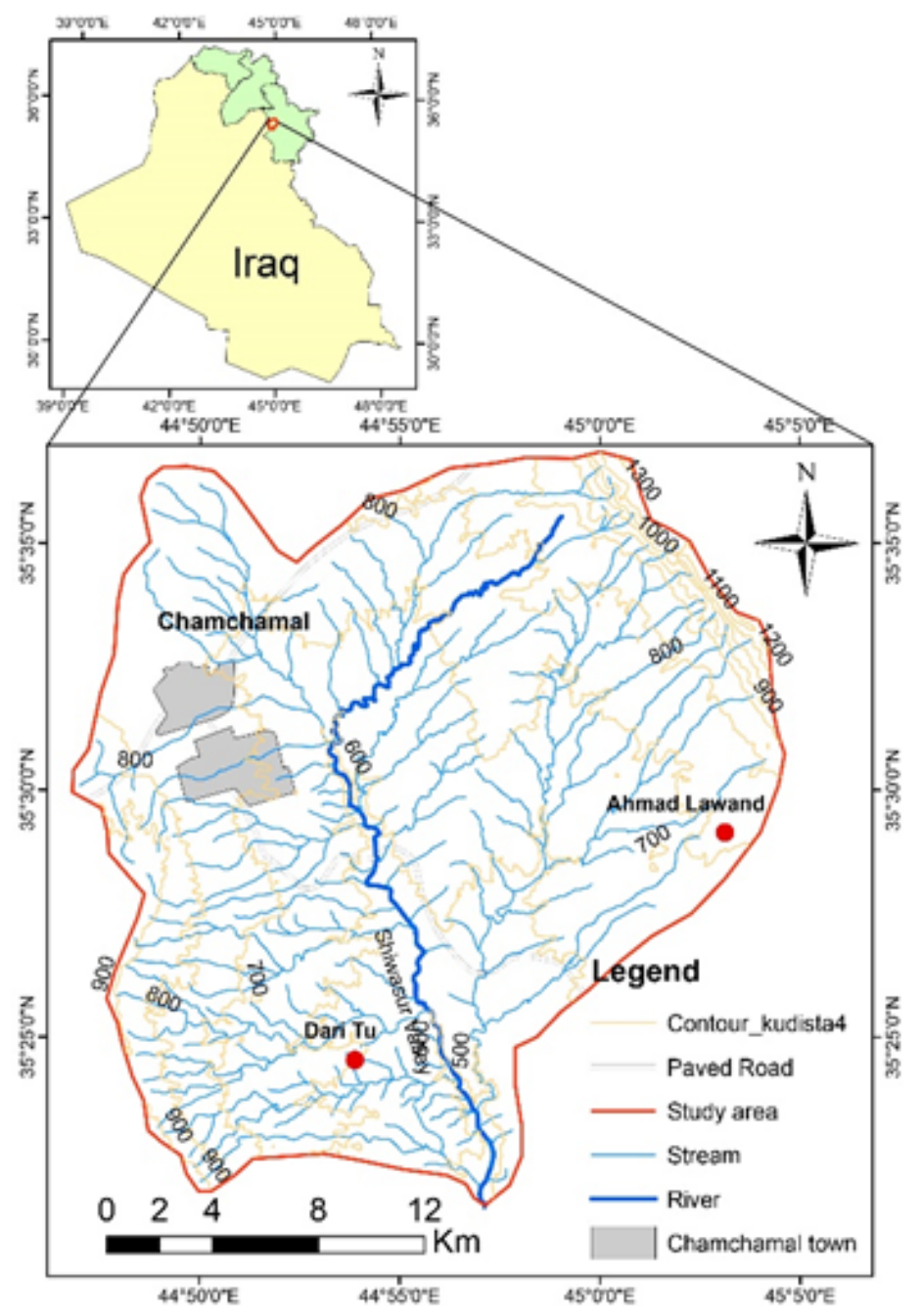

Fig. 1. Location map of the study area.

\section{Geological and Hydrogeological framework of the study area}

According to (Jassim \& Goff, 2006), the age of rock units is ranged from middle to upper Eocene to recent, as shown in Figure 2. The oldest one is the Pila Spi formation (MiddleUpper Eocene), composed of well-bedded limestone, dolomitic, and chalky limestone. The thickness of Pila Spi varies between 100200m. Fatha formation (Middle MioceneTortonian) is composed of anhydrite gypsum and salt interbedded with limestone, marl, and relatively fine-grained clastics. The thickness of the formation in the study area reached $447.5 \mathrm{~m}$ in well No.2 in Chamchamal (Al-Mirally, 2006). The other rock unit that belongs to Late Miocene is the Injana formation that comprises thin-bedded calcareous sandstone, red and green mudstone with thin gypsum bed $(20 \mathrm{~cm}$ thick), and purple siltstone horizon with glass shards. The thickness of the formation in the study area is approximately $650 \mathrm{~m}$. The northeastern and southwestern parts are covered by Mukdadiya and Bai Hassan formations (Pliocene), composed almost purely of terrigenous clastic from silt size to bounder conglomerates. The thickness of the Mukdadiya is approximately $650 \mathrm{~m}$ while Bai Hassan is $150 \mathrm{~m}$ thick (Stevanovic \& Markovic, 2004a). Slope sediments are formed along the flanks of the structures. The sediments filling the synclines consist mainly of a mixture of gravel and clay.

Systems in the study area resulted from the presence of different geological formations and many aquifers (Figure 3). The dominant 
aquifer systems in the study area are the Mukdadiya and Bai Hassan intergranular and Pila Spi karstic fissured aquifers, which are penetrated by many good production wells, and they are used for different purposes. Furthermore, the other aquifer systems have low production and are characterized by a high content of dissolved solids due to the presence of clay and gypsum layers. The highest water table is recorded in the northeast and northwest boundary of the basin. Groundwater flow occurs from the Bani Maqan plateau and Darband Bazian mountain toward the Chamchamal plain located in the middle of the study area.

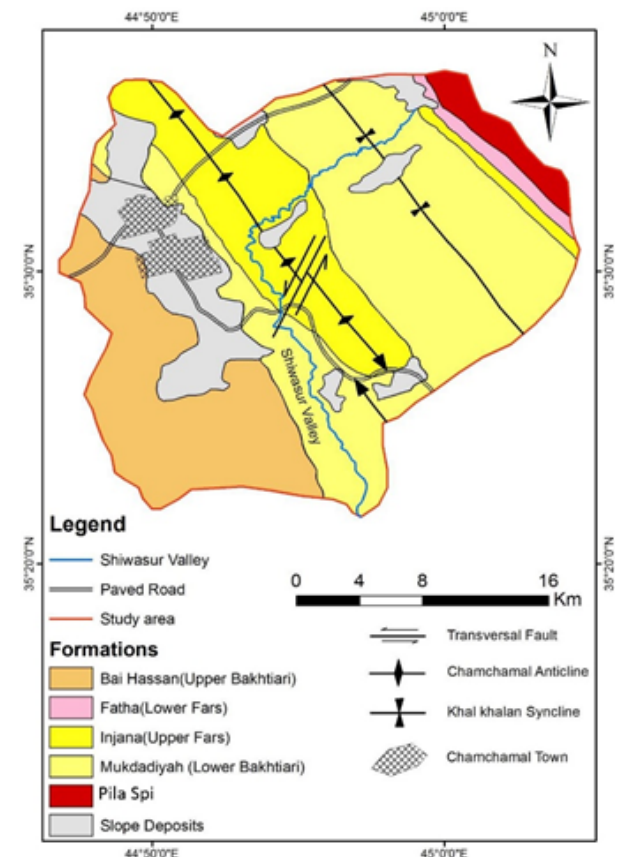

Fig. 2. Geology map of Chamchamal basin.

\section{Methodology}

To delineate groundwater potential areas for this study, the various parametric dataset used, including Landsat8 satellite image, conventional maps, data from the relevant Directorates, and ASTER. The detailed procedure of this work is presented in Figure 4. The soil layer is prepared by digitizing the soil map of FAO. (2002). Remote sensing data, PCI Geomatica 2016, and ARC GIS

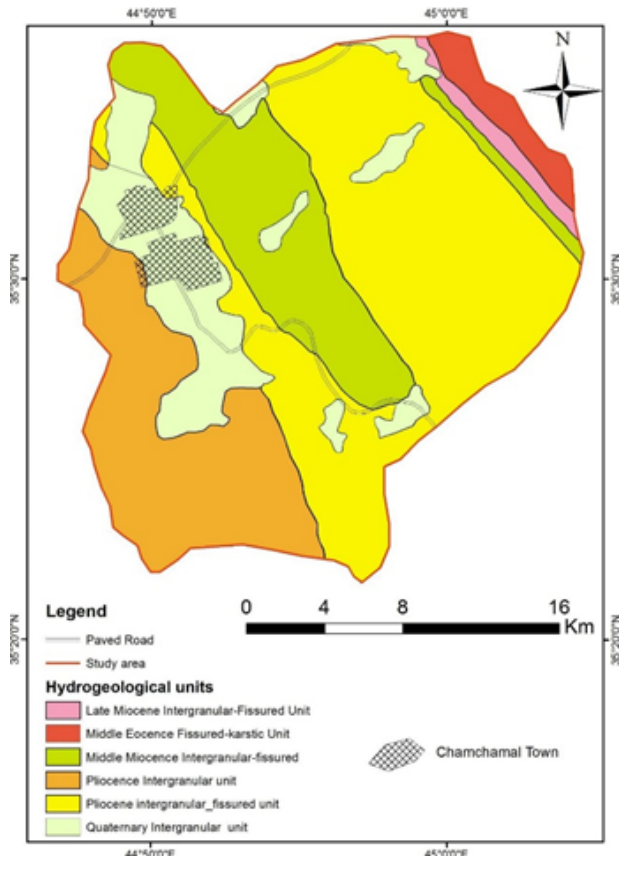

Fig. 3. Hydrogeology map of Chamchamal basin.

10.5 software have been used for thematic map preparation like lineament density, drainage density, soil, and slope of the area of interest. Land cover was prepared by using Landsat TM data with a spatial resolution of $30 \mathrm{~m}$. The source of data used for the current study is tabulated in Table 1.

A consequence of a finite combination of the important factor like climate, geology, topography, soil, land cover/ land use, slope, drainage pattern, geomorphology, etc. that together make an integrated dynamic system which affects on groundwater occurrence and distribution (Arkoprovo et al., 2012). To evaluate groundwaterresources, potential zones of an area will be predicted by studying these factors and their relationships. The thematic layers in groundwater potential studies include elevation, slope angle, aspect, topographic wetness index, stream power index, length steepness, lithological units, hydrological soil group normalized vegetation index (NDVI), the hydraulic property of the aquifer. Distance to (faults, river, roads) is often used, until now, there is no systematic procedure for selecting them; the process depends on the availability. 
Table 1. The sources of data for the present study.

\begin{tabular}{|llll||}
\hline Data & Source & Thematic laver & Resolution \\
Digital elevation & ALOS PALSAR & Drainage density & $12.5 \mathrm{~m}$ \\
model (DEM) & DEM & Slope & $12.5 \mathrm{~m}$ \\
& & Topography & $12.5 \mathrm{~m}$ \\
Satellite image & USGS & Land use and land & $30 \mathrm{~m}$ \\
Landsat 8, July 2017 & & Lineament density & $30 \mathrm{~m}$ \\
In situ Data & FAO & Soil & $12.5 \mathrm{~m}$ \\
& Iraqi Geological & Geology & $12.5 \mathrm{~m}$ \\
\hline
\end{tabular}

\subsection{Groundwater potential mapping concept}

The integration of several assessment procedures like geological, geophysical, hydrogeological, and metrological methods might be used to delineate the groundwater potential areas. About decades ago, modern techniques like remote sensing (RS) and Geographic Information system (GIS) had become powerful tools to find groundwater, assessment, and protection as well. The thematic maps like geology, geomorphology, soil, drainage density, lineaments, and slope maps from different sources such as RS, conventional data, and literature data are combined into GIS to create groundwater potential index.

To calculate the groundwater potential index (GWPI), a combination of the weighted linear method assigns a weight to each factor according to the equation given below (Malczewski, 1999).

Various thematic layers are used to conduct groundwater potential mapping. The number and types of the thematic layer are different from one study to another depending on the possible and accessible data in the area of interest.

The thematic maps are derived from different sources, including geologic, geomorphology, soil, satellite image, and the water well data (discharge and water level). The thematic maps have their rank according to the importance of groundwater condition and the possibility of occurrence. Several classes are made for the factors based on the hydrogeological characteristics, after that giving the rank and weight for each one depending on their importance for groundwater potential determination.
Analytical hierarchy processes (AHP) are used to derive the thematic raster layers with their weights for each factor. This process can be considered as one of the multi-criteria decision-making models (MCDM). Under the uncertain condition systematically, the MCDM is helping the decision-makers to select the best acceptable choices (Al-Abadi et al., 2017). The Analytical hierarchy process (AHP) gives cost-effective, easy, and logical output for multi-parameter problems when the main disadvantage depends on the authority's information which will be the key source of the doubt (Saaty, 1980).

\subsection{Generation thematic maps}

Six thematic maps include (geology, lineament density, slope, soil, drainage density, LU/LC) were generated using DEM data, conventional data, and previous works concerning the area of interest with the help of ArcGIS 10.5 software. The mechanism of thematic layers selection depends on the expert knowledge, and personal opinion, the detail of thematic layers is described in the following topics.

\subsubsection{Geology}

The essential petrophysical properties like rocks, porosity, and permeability are controlled by geology. Exceptional petrophysical properties (higher porosity and permeability) can give maximum storage of groundwater capacity. Porosity mainly affects the storage capacity of the rock units, the movement of water from recharge area to discharge area under the effect of the hydraulic head based on hydraulic 


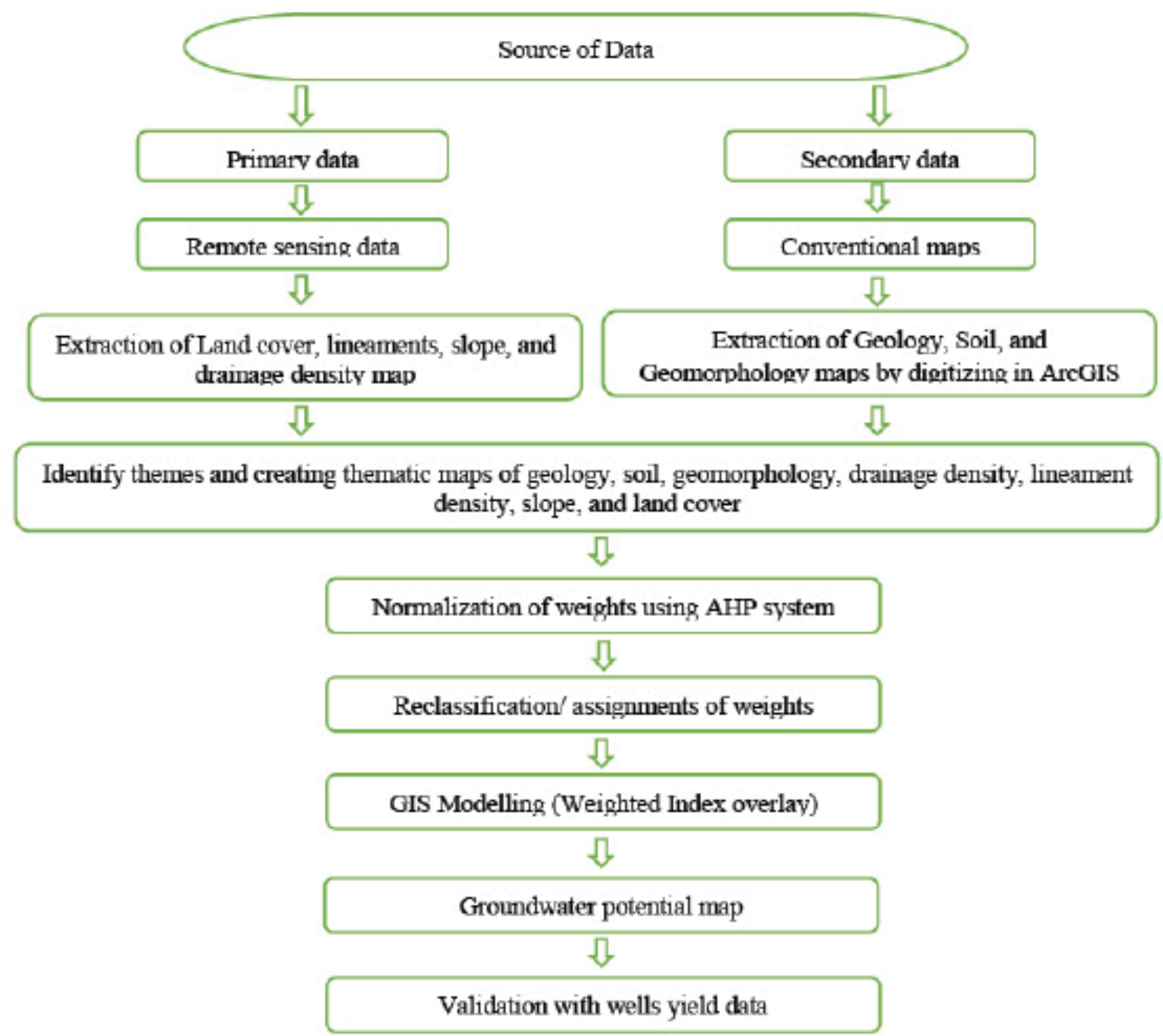

Fig. 4. Groundwater potential mapping procedure.

Where:

$$
\text { GWPI }=\sum_{j=1}^{m} * \sum_{\mathrm{i}=1}^{\mathrm{n}}\left(\mathrm{w}_{\mathrm{j}} \mathrm{r}_{\mathrm{i}}\right) \ldots \ldots \text { (1) }
$$

GWPI: Groundwater potential index

$\mathrm{w}_{-} \mathrm{j}$ and $\mathrm{r}_{-} \mathrm{i}$ : is the weight of $\mathrm{J}$ theme and rank of $\mathrm{i}$ class

$\mathrm{m}$ : The total number of themes

$\mathrm{n}$ : The total number of feature classes.

conductivity and permeability (Al-Mirally, 2006; Manikandan et al., 2014; Kumar et al., 2016). The geology of the area described by (Buday, 1980; Buday \& Jassim, 1987; Sissakian, 1997; Jassim \& Goff, 2006), used in this study. In the study area, Quaternary deposits, conglomerates, and limestone were considered as the essential importance of groundwater storage. On the contrary, clay, gypsum, and marl were considered the least important for groundwater storage due to their primary and secondary porosity. The Eocene calcareous Pila Spi formation was expected to have better groundwater storage than other Miocene formations like Fatha and Injana formation as fractures and karstic features (Figure 5a).

\subsubsection{Lineament density}

The simple and complex linear properties of geological structures such as faults and 
fractures are arranged in a straight or curvy line; using remote sensing, it is possible to obtain discontinuities defined as lineaments (O'Leary et al., 1976). Many factors that can affect rock's geological behavior, such as the nature of deformation, can cause a change in size and shape direction of lineaments. (Mohammadi-Behzad et al., 2018). PCI Geomatica (2016) software was used to interpret the lineament distribution for the area extracted from nine bands of Landsat 8 Thematic Mapper (TM) images, with $30 \mathrm{~m}$ spatial resolution. The lineament density map was classified into four classes (Figure 5b): 0-0.33 (very low), 0.34-0.66 (low), 0.67-0.99 (moderate), and1.0-1.3 (high) $\mathrm{km} / \mathrm{km} 2$. The southern part of the study area is characterized by the highest lineament density suitable for groundwater development.

\subsubsection{Slope}

The slope is considered one of the main factors that influence groundwater and surface catchment characteristics. Lower slope angles lead to a lower hydraulic gradient, which leads to improving the recharge and infiltration (Rauf, 2014). The DEM data was used for drawing the slope map of the interest areas. The relation of the slope with groundwater is proportional to the degree of slope. ( Ribolzi et al., 2011). The slope map is classified into five groups (Figure 5c). The areas having a $0^{\circ}-3.2^{\circ}$ slope are classified as 'very good' because of the flat area and almost decreased runoff flow downstream. The second group has a slope of $3.3-6.7^{\circ}$; most of the study area has a low slope, in which the groundwater can be easily recharged. The third group is ranged between $6.8-12^{\circ}$, whilst the fourth group is between $13-22^{\circ}$, and the fifth group is $23-51^{\circ}$. The last two groups are considered as 'moderate' and 'poor' for groundwater occurrence due to the steeper slope, which makes the higher runoff.

\subsubsection{Soil}

Different types of soil might influence ground-water due to the infiltration process. In the study area, three soil types are classified based on (Buringh, 1957) and Food and Agriculture Organization (FAO, 2003) work. The classification of soil type is (C3) called brown soil that covers most of the area, which is recognized as calcic and gravely soil with erosional features as well. The second type is $(\mathrm{C} 2,1)$ called reddish-brown soil, which is silty and sandy soil enriched with gypsiferous sail land. Finally, the third type is (B1), known as stonland soil, mainly gravelly and rocky soil (Figure 5d).

\subsubsection{Land use and land cover}

Land use and land cover are some of the parameters that reduce the surface runoff, increase groundwater occurrence in the study area, or catch water on their leaves (James, 2001). Water droplets percolating downward lead to the recharge process of groundwater. The major land-use types in interest areas are vegetation, agricultural land, and few water bodies and river parts. Land use and land cover map were prepared using Landsat- 8 images and ENVI 5.1 software. Thus, the study area is classified into five types: scrub/ shrub, grassland/agriculture, water, barren sparsely vegetated, and build-up (Figure $5 \mathrm{e})$.

\subsubsection{Drainage density}

The spacing between the stream channels and a measure of length in square kilometers is defined as drainage density. Permeability is an inverse function of drainage density (Bera \& Ahmad, 2016). Less drainage density is related to a higher potential of groundwater (Rauf, 2014). ArcGIS 10.5 was used for the kriging interpolation technique to conduct the line density of spatial analysis tool, conducted from drainage lines. Consequently, a mesh network was used in the study area, and the drainage density index was measured. The obtained values for each mesh were plotted at the center of the grid, and by using, the coordinates of the center of each mesh, the drainage density map are produced (Figure 5f). The drainage 

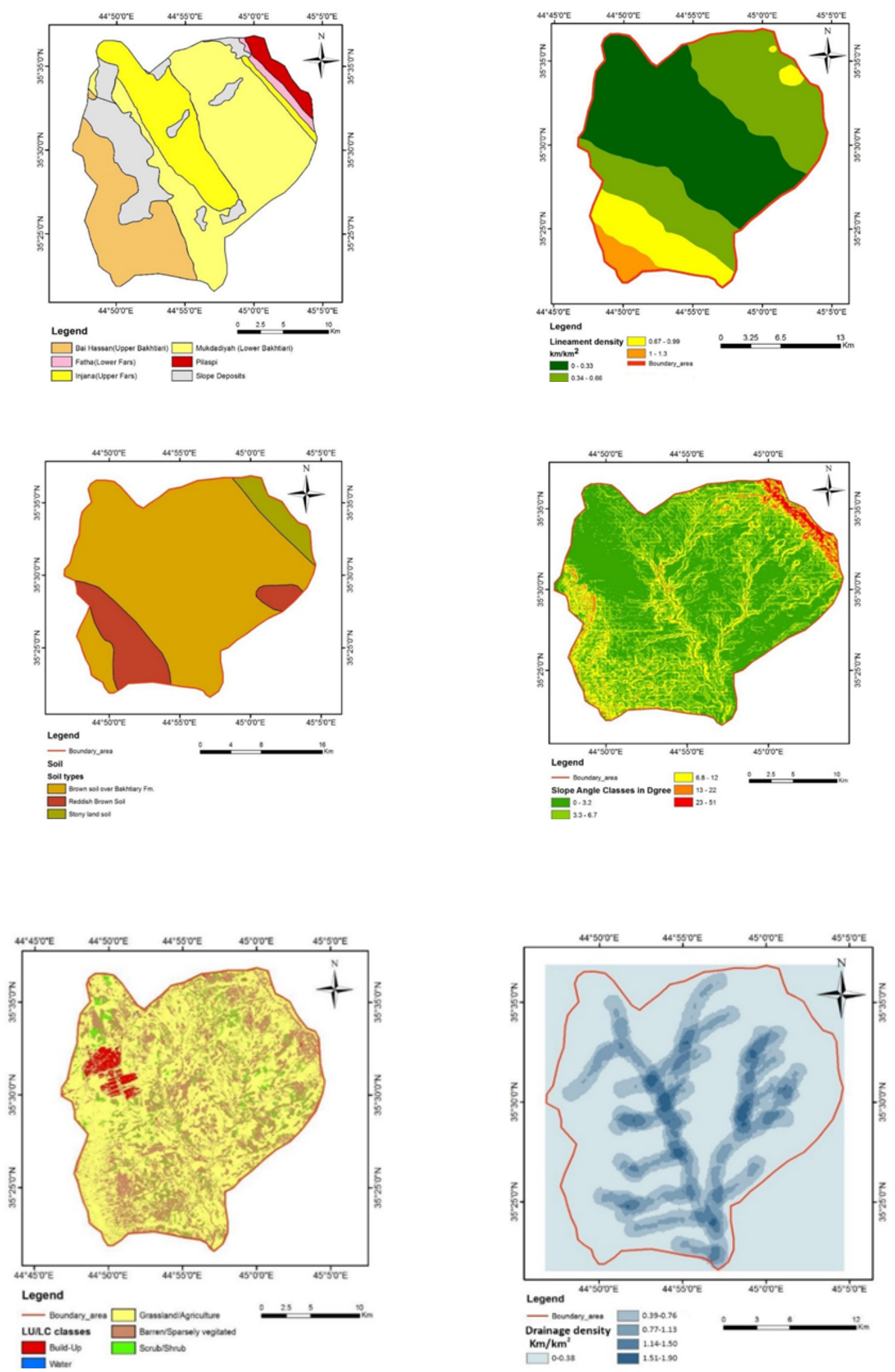

Fig. 5. The output of thematic maps, geology, b lineament density $(\mathrm{km} / \mathrm{km} 2)$, c soil (descriptions), d slope $\left({ }^{\circ}\right)$, e land use/land cover (classes), f drainage density $(\mathrm{km} / \mathrm{km} 2)$. 
Table 2. Groundwater potential classes and their Ranks and weights.

\begin{tabular}{|c|c|c|c|c|}
\hline Theme & Class & $\begin{array}{l}\text { Groundwater } \\
\text { prospect }\end{array}$ & Rank & weight $\%$ \\
\hline \multirow[t]{6}{*}{ Geology } & Quaternary deposits & Very good & 6 & $34.70 \%$ \\
\hline & Bai Hassan Formation & Very good & 6 & \\
\hline & Mukdadya Formation & Fairly good & 4 & \\
\hline & Injana Formation & Poor & 2 & \\
\hline & Fatha Formation & Poor & 2 & \\
\hline & Pilaspi Formation & Fairly good & 4 & \\
\hline Lineament & $1.0-1.3$ & High & 5 & $28.0 \%$ \\
\hline \multirow[t]{3}{*}{ Density } & $0.67-0.99$ & Moderate & 4 & \\
\hline & $0.34-0.66$ & Low & 2 & \\
\hline & $0-0.33$ & Very low & 2 & \\
\hline \multirow[t]{5}{*}{ Slope } & $0 .-3.2$ & Very good & 6 & $13.40 \%$ \\
\hline & $3.3-6.7$ & Good & 5 & \\
\hline & $6.8-12$ & Fairly good & 4 & \\
\hline & $13-22$ & Moderate & 3 & \\
\hline & $23-51$ & Poor & 1 & \\
\hline \multirow[t]{3}{*}{ Soil } & C3 (Brown Soil) & Moderate & 3 & $10.60 \%$ \\
\hline & C2,1 (Reddish Brown Soil) & Moderate & 3 & \\
\hline & B2 (Stonland soil) & Poor & 2 & \\
\hline \multirow{5}{*}{$\begin{array}{l}\text { Land use and } \\
\text { land cover }\end{array}$} & Scrub/Shrub & Very good & 6 & $8.80 \%$ \\
\hline & Grassland/Agriculture & Fairly good & 4 & \\
\hline & Water & Good & 5 & \\
\hline & Barren Sparsely Vegetated & Fairly good & 3 & \\
\hline & Build-Up & Poor & 1 & \\
\hline Drainage & $0-0.38$ & Very good & 6 & $4.60 \%$ \\
\hline \multirow[t]{4}{*}{ Density } & $0.38-0.76$ & Good & 5 & \\
\hline & $0.77-1.13$ & Fairly good & 3 & \\
\hline & $1.14-1.50$ & Moderate & 3 & \\
\hline & $1.51-1.90$ & Poor & 2 & \\
\hline
\end{tabular}

density map of the area is classified into five classes: $0-0.38$ (very good), $0.39-0.76$ (good), 0.771 .13 (fairly good), 1.14-1.50 (moderate) and 1.51-1.9 (poor). The higherranking value was assigned to low drainage density areas and lower rankings to denser drainage areas, as presented in (Table 2). The central part of the basin is characterized by high drainage density.

\section{Results and discussion}

4.1. Assigning weights for thematic layers using analytical hierarchy process (AHP)
The thematics map is integrated into the GIS software, and each selection relatively depends on the relative importance of the map. The true image of groundwater accessibility and the features of the maps should be built using (AHP) or through an individual decision of the experts. Saaty, 1980, provided and developed a flexible and understandable way to solve a complicated problem (Jenifer \& Jha, 2017; MohammadiBehzad et al., 2018).

The software Expert Choice EC 2000'TM is used to implement the analytical hierarchy process, a powerful application that enables 
Table 3. Normalized weights and consistency ratio of pair-wise comparison of themes.

\begin{tabular}{|c|c|c|c|c|c|c|c|c|}
\hline & Geology & $\begin{array}{l}\text { Lineamen } \\
t \text { density }\end{array}$ & Slope & Soil & $\mathrm{LU} / \mathrm{LC}$ & $\begin{array}{c}\text { Drainage } \\
\text { density }\end{array}$ & weight & $\begin{array}{l}\text { Normalized } \\
\text { weight AHP }\end{array}$ \\
\hline Geology & & 1 & 3 & 4 & 4 & 7 & 0.347 & 34.7 \\
\hline Lineament density & & & 2 & 3 & 3 & 5 & 0.280 & 28.0 \\
\hline Slope & & & & 1 & 2 & 3 & 0.134 & 13.4 \\
\hline Soil & & & & & 1 & 3 & 0.106 & 10.6 \\
\hline $\mathrm{LU} / \mathrm{LC}$ & & & & & & 2 & 0.088 & 8.8 \\
\hline Drainage density & & & & & & & 0.046 & 4.6 \\
\hline \multicolumn{9}{|c|}{ Consistency Ratio: $1 \%$} \\
\hline
\end{tabular}

ordering objectives and assessing alternatives, and realizing arrangement. The weight of each thematic map is calculated depending on pair-wise comparison and significance of the geology, lineament density, slope, soil, LU/LC, and drainage density maps (Table 2). It is noticeable that the geology layer has the greatest weight (34.7\%) and, consequently, the most important, while the drainage density layer has the lowest weight $(4.6 \%)$ and the miniature importance density layer has the lowest weight $(4.6 \%)$ and miniature importance. The thematics map is integrated into the GIS software, and each selection relatively depends on the relative importance of the map. The true image of groundwater accessibility and the features of the maps should be built using (AHP) or through an individual decision of the experts. Saaty. 1980, provided and developed a flexible and understandable way to solve a complicated problem (Jenifer \& Jha, 2017; Mohammadi-Behzad et al., 2018).

The weights of each thematic map were put depending on the local geologists' and hydrogeologists' expert opinions. Then the thematic layers are compared upon each other in a pairwise correlation matrix (Table 3). After that, the assigned weights were normalized and reclassified using Saaty's AHP. The normalization method decreases the character correlated with the designated weights of the thematic layers and their features. The ranking and the weighting of the six maps and their attributes were less than $10 \%$, so the given weight is reliable. The six maps are reclassified to all thematic layers based on assigned weight converted to raster data with $30 \times 30 \mathrm{~m}$ cell size. To achieve the best results, the consistency ratio (CR) must be applied for the normalization process as suggested by (Saaty, 1980). The consistency ratio is calculated using equation 2 .

$$
\mathrm{CR}=\mathrm{CI} / \mathrm{RCI} \ldots \ldots(2)
$$

Where $\mathrm{CI}$ is the consistency index, and RCI is a random consistency index. The $\mathrm{CI}$ is calculated from (Saaty, 1980) equation:

$$
\mathrm{CI}=\frac{\lambda_{\max }}{\mathrm{n}-1}
$$

where $\mathrm{n}$ is the number of criteria or factors (Saaty, 1980) revealed that the $C R$ value should be less than 0.1 unless the results must subject to reevaluation. The calculated value of CR for the present study was 0.01 , which indicates a high consistency. 4.2 GIS modeling and groundwater potential map

The Model Builder tool in GIS is used to construct the model, edit and manage the model process; different criteria considered input dataset and goes through the workflow process to finding the output dataset layer; this model used to clarify the workflow process, which is a visual programming language in GIS shown in Figure 6. The combined reclassified input themes in GIS using the processing of rater calculation techniques to conduct a potential map depend on a combination of the weighted linear method (Malczewski, 1999; Ahmed \& Sajjad, 2018):

$$
\mathrm{GWP}=\sum_{\mathrm{j}=1}^{\mathrm{m}} * \sum_{\mathrm{i}=1}^{\mathrm{n}}(\mathrm{wj} * \mathrm{xi}) \ldots \ldots .
$$

$\mathrm{M}$ is the total number of themes.

$\mathrm{N}$ is the total number of classes in a theme. The six reclassified thematic maps are summed on overlay analysis based on the assigned weight and then integrated into ArcGIS using equation (4) to conduct the final weight map as shown in Fig.7. The map 
Where:

$\mathrm{xi}$ is the normalized weight of the I feature of themes

$\mathrm{wj}$ is the normalized weight of the $\mathrm{j}$ themes

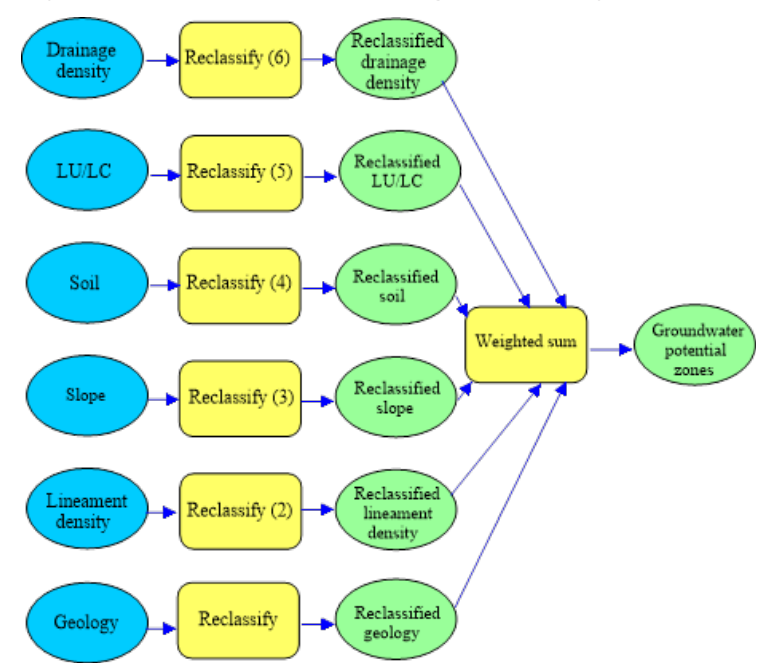

Fig. 6. Groundwater potential model workflow of the area of interest in Model Builder of ArcGIS.

shows the probability of groundwater existence in the area. The generated final map was classified depending on the groundwater potentiality into four classes: good, moderate, poor, and very poor potential areas. The areas of the potential zones are listed in Table 4.
Table4. Areas and percentages of groundwater potential zones in Chamchamal basin.

\begin{tabular}{|lll|}
\hline $\begin{array}{l}\text { Groundwater } \\
\text { potential } \\
\text { zones }\end{array}$ & $\begin{array}{l}\text { Area } \\
\left(\mathrm{km}^{2}\right)\end{array}$ & $\begin{array}{l}\text { Area } \\
(\%)\end{array}$ \\
Good & 55.2 & $10.4 \%$ \\
Moderate & 204.4 & $38.7 \%$ \\
Poor & 232.2 & $43.93 \%$ \\
Very Poor & 36.8 & $6.96 \%$ \\
\hline
\end{tabular}

The probable explanation is that good groundwater potential zones mainly encompasses Quaternary deposits and Bai Hassan formation, which covers the south and western part of the area, and some area from the middle of the eastern part of the study area. The most eastern and middle parts are poor areas; the rest parts are moderated areas.

Validation of any model is required before explaining the model, either stochastic or deterministic. Scientifically the importance of the model is based on the validation (AlManmi \& Rauf, 2016).

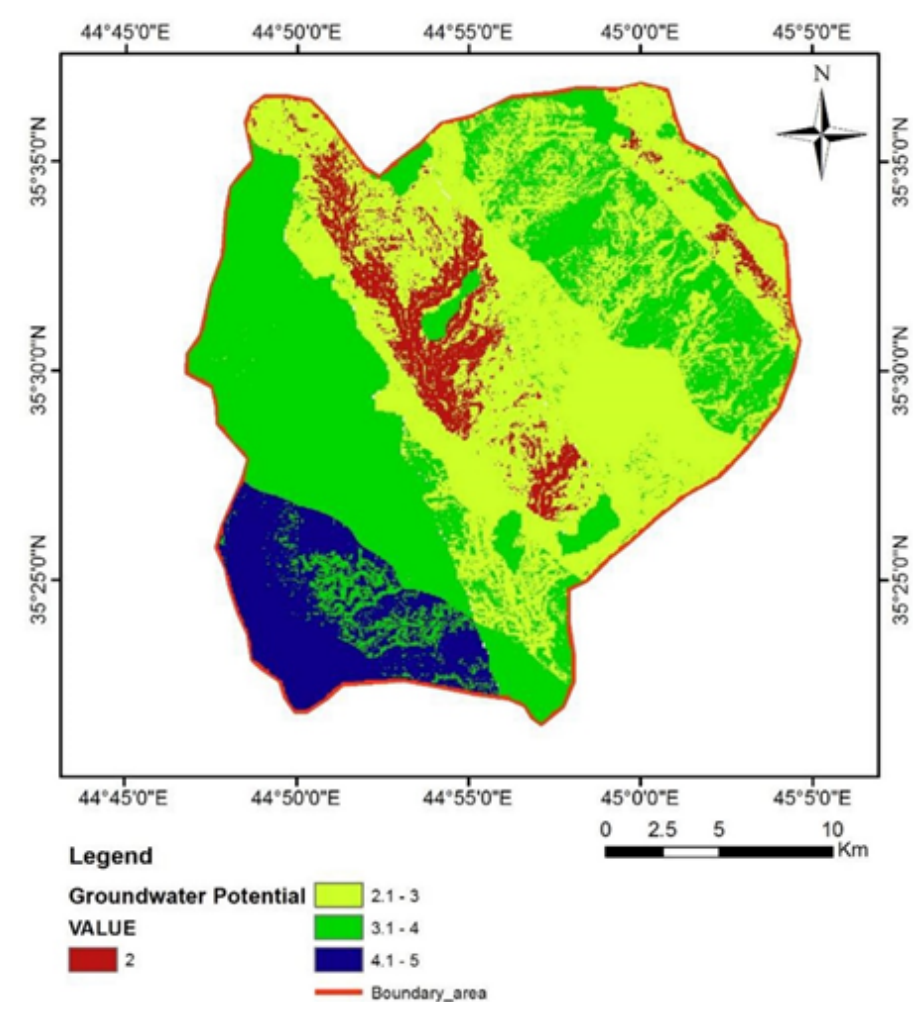

Fig. 7. Groundwater potential zones of the study area. 


\subsection{Model validation}

To validate the classified zones of groundwater potential zones (good, moderate, low), the wells yield data from 38 wells were introduced to the model. The yield data of the wells are categorized into good ( $>79$ gallons/minute), moderate (2479 gallon/minute), and poor yield ( $<24$ gallons/ minute). Such a validation method was used by many researchers like (Shekhar \& Pandey, 2015; Agarwal \& Garg, 2016; Al-Manmi \& Rauf, 2016, and Panahi et al., 2017). The groundwater potential areas that are GIS-based potential zones of characteristics good to low possible areas. The potential areas are validated and created over this model that is shown in Figure 8. It is important to gain information and point out from the generated map model, which assists the scheming process of appropriate groundwater survey and management in upcoming decades. The generated map model shows the spatial distribution of geology parameters, lineaments, slope, soil, LU/LC, and drainage density. The good groundwater potential areas are distributed along with quaternary and Bai Hassan formations with high lineament density and a low degree of slopes. From this point of view, lineaments and geology are the important factors affecting water storage in groundwater investigations. The moderate groundwater potential areas contribute to the combinations of the lineament density, drainage density, slope, and soil. The poor potential area is spatially distributed mainly along with Eocene and Miocene formations, stony land soil, low areas of lineaments, and high to very high slope areas as well. The most important parameters are geology (Quaternary deposits and Bai Hassan formation) and dense lineaments in the study area.The LU/ LC factors are also important in the aspects of groundwater, especially vegetation cover, which is a good indicator of shallow groundwater due to the green vegetation type indicating soil moisture property. (Rauf, 2014) However, in the study area, the vegetation is not an important factor except for agriculture due to semi-arid conditions. The soil has an important impact on groundwater recharge as well, but the area except the eastern part is tony soil; the other parts have the same effect, respectively. Validation by the wells reveals that some areas are good in the aspects of groundwater, but the well shows poor yield due to the variation in local geology, such as the lenses that act as a barrier. Moreover, in the moderate zones, some wells show moderate or high yield, but as a result, this method and according to the available data, the accuracy of the work also changes.

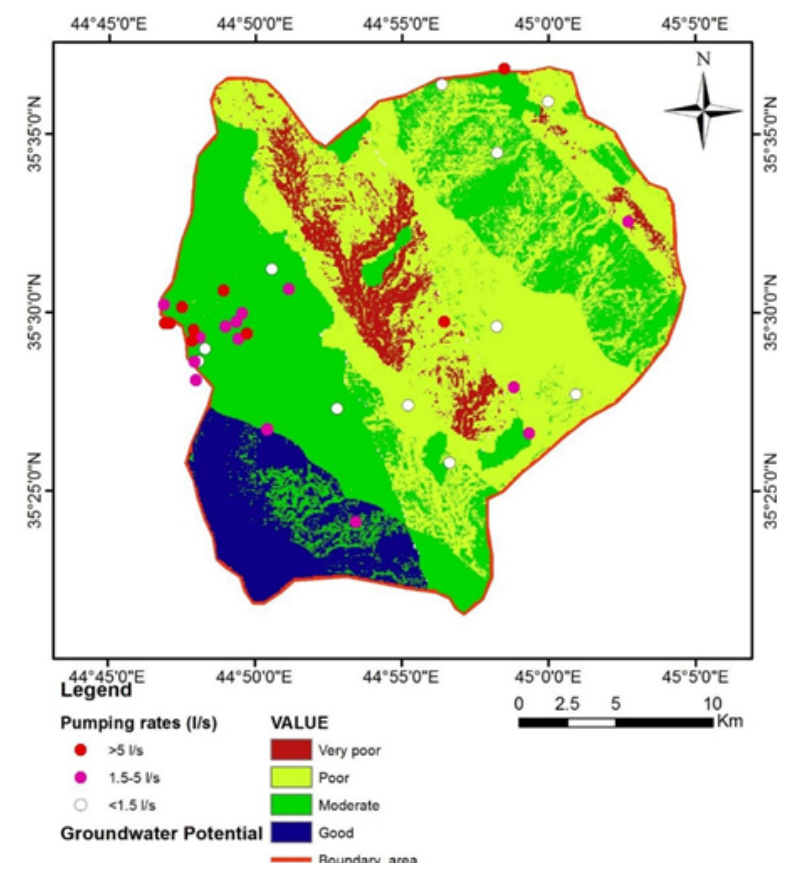

Fig. 8. Overlying of effective wells on groundwater potential zone. 


\section{Conclusion}

The delineation and groundwater potential zoning of the Chamchamal basin confirmed that the remote sensing and GIS techniques are powerful and cost-effective techniques. This method is an effective way to minimize time consumption, cost, labor, and it can lead to quick decision-making for sustainable groundwater resources management in the area. The thematic layers, which are reclassified based on each class's assigned weight, then integrated into the GIS environment through the model processing to prepare groundwater potential areas based on weighted sum analysis, are considered a suitable tool in the groundwater potential zoning. Depending on the modeling results, the groundwater potential map was divided into four zones representing good, moderate, poor, and very poor groundwater potentials cover 55.2, $204.4,232.2$, and $36.8 \mathrm{~km} 2$ of the study area, respectively. In other words, they cover nearly $10.4,38.7,43.93$, and $6.96 \%$ of the area. The verification shows that GIS and AHP methods are representatives of determining the potential zones. Although AHP provides a flexible, low cost, and readable output for difficult decision-making problems, it undergoes a main disadvantage, which is associated with dependence on expert's knowledge, the major source of uncertainty. The best potential area concentrated in the southwest of the area when the Bai Hassan formation exposed is considered a good intergranular aquifer. This study's results help the decision-makers plan for future groundwater management and sustainability of the Chamchamal area, especially because the area is suffering from a lack of potable water.

\section{ACKNOWLEDGEMENTS}

The authors would like to give many thanks and respect to the consultant Dr. Janos Vago, in the department of geography of University Miskolc, for his effort and continuous guide. Special thanks go to the Sulaymaniyah
Groundwater Directorate for providing wells data. Great thankfulness goes to $\mathrm{Mr}$. Nawroz M. Omer and all the geologists for their support and guidance during fieldwork.

\section{References}

Agarwal, R., \& Garg, P. (2016). Remote sensing and GIS-based groundwater potential and recharge zones mapping using multi-criteria decision-making technique. Water Resources Management, 30(1):243260.

Ahmed, R., \& Sajjad, H. (2018). Analyzing factors of groundwater potential and its relation with a population in the Lower Barpani watershed, Assam, India. Natural Resources Research, Pp.1-13.

Al-Abadi, A.M., \& Al-Shamma'a, A. (2014). Groundwater potential mapping of the major aquifer in Northeastern Missan Governorate, South of Iraq, by using analytical hierarchy process and GIS. Journal of Environ and Earth Science, 4(10):125149.

Al-Abadi, A.M., Pourghasemi, H. R., Shahid, \& Ghalib, H. B. (2017) Spatial mapping of groundwater potential using entropy weighted linear aggregate novel approach and GIS. Arabian Journal for Science and Engineering, 42(3): 1185-1199.

Al-Manmi, D.A.M., \& Rauf, L.F. (2016). Groundwater potential mapping using remote sensing and GIS-based, in Halabja City, Kurdistan, Iraq. Arabian Journal of Geosciences, 9(5):357.

Al-Mirally, T.H. (2006). Study of geophysical evidence to define properties of some structures at low folded zone in Kurdistan Region-Iraq. M.Sc. thesis, University of Sulaimani, Sulaymaniyah, Iraq. 
Arkoprovo, B.; Adarsa, J.; Prakash, S.S. (2012). Delineation of groundwater potential zones using satellite remote sensing and geographic information system techniques: A case study from Ganjam district, Orissa, India. Research Journal of Recent Sciences, 1(9): 59-66.

Bera, S., \& Ahmad, M. (2016). Site suitability analysis using remote sensing \& GIS for rainwater harvesting. International Journal of Geology, Earth \& Environmental Sciences 6(2):101-110.

Buday, T. (1980). The regional geology of Iraq, Vol. I. Stratigraphy and Paleogeography. I.I.M. Kassab and S.Z.Jassim (Eds). SOM, Baghdad, Dar El Kutib Publ. House, University of Mosul. Pp. 445.

Buday, T. \& Jassim, S. Z. (1987). The regional geology of Iraq, Vol. II: Tectonism, Magmatism, and Metamorphism. Pp. 352.

Buringh, P. (1957). Exploratory soil map of Iraq. Ministry of Agriculture, Baghdad.

Chandio, I.A.; Matori, A.N.B.; WanYusof, K.B.; Talpur, M.A.H.; Balogun. et al. (2013). GIS-based analytic hierarchy process as a multi-criteria decision analysis instrument: a review. Arabian Journal of Geosciences, 6(8): 3059-3066.

Fashae, O.A.; Tijani, M.N.; Talabi, A.O., \& Adedeji, O.I. (2014). Delineation of groundwater potential zones in the crystalline basement terrain of SW-Nigeria: an integrated GIS and remote sensing approach. Applied Water Science, 4(1):1938.

Hajkowicz, S., \& Collins, K. (2007). A review of multiple criteria analysis for water resource planning and management. Water Resources Management 21(9): 1553-1566.
Islami, N.; Taib, S.H.; Yusoff, I., \& Ghani, A.A. (2018). Integrated geoelectrical resistivity and hydrogeochemical methods for delineating and mapping heavy metal zone in the aquifer system. Journal of Environmental Earth Science, 77(10):383.

James, R. A.; Ernest, E. H.; John, T. R., \& Richard, E. W. (2001). A land use and land cover classification system for use with remote sensor data, Geological Survey professional paper 964, Washington. Pp. 41.

Jassim, S. Z. \& Goff, J. C. (eds.) (2006). Geology of Iraq. Dolin, Prague and Moravian Museum, Brno. Pp. 341.

Jenifer, M.A., \& Jha, M.K. (2017). Comparison of analytic hierarchy process, catastrophe, and entropy techniques for evaluating groundwater prospect of hardrock aquifer systems. Journal of Hydrology, 548: 605-624.

Jha, M.K.; Chowdary, V., \& Chowdhury, A. (2010). Groundwater assessment in Salboni Block, West Bengal (India) using remote sensing, geographic information system, and multi-criteria decision analysis techniques. Hydrogeology Journal, 18(7):1713 1728.

Kaliraj, S.; Chandrasekar, N., \& Magesh, N.S. (2014). Identification of potential groundwater recharge zones in Vaigai upper basin, Tamil Nadu, using GIS-based analytical hierarchical process (AHP) technique. Arabian Journal of Geosciences 7(4):1385-1401.

Krishnamurthy, J.; Venkatesa Kumar, N.; Jayaraman, V., \& Manivel, M. (1996). An approach to demarcate groundwater potential zones through remote sensing and a geographical information system. International Journal of Remote Sensing, 17(10): 1867-1884. 
Kumar, P.; Herath, S.; Avtar, R., \& Takeuchi, K. (2016). Mapping of groundwater potential zones in Killinochi area, Sri Lanka, using GIS and remote sensing techniques. Sustainable Water Resources Management, 2(4): 419-430.

Malczewski, J. (1999). GIS and multicriteria decision analysis. John Wiley \& Sons, Inc, New York.408 Pp.

Manikandan, J.; Kiruthika, A. M., \& Sureshbabu, S. (2014). Evaluation of groundwater potential zones in Krishnagiri District, Tamil Nadu using MIF technique. International Journal of Innovative Research in Science Engineering and Technology, 3(3): 10524-10534

Minor, T.B.; Carter, J.A.; Chesley, M.M.; Knowles, R.B., \& Gustafsson, P. (1994). The use of GIS and remote sensing in groundwater exploration for developing countries (No. USATEC-R-236). Beloir, VA: Army Topographic Engineering Center Fort.

Mogaji, K.A.; Omosuyi, G.O.; Adelusi, A.O., \& Lim, H.S. (2016) Application of GIS-based evidential belief function model to regional groundwater recharge potential zones mapping in Hardrock geologic terrain. Environmental Processes. 3(1): 93-123.

Mohammadi-Behzad, H. R.; Charchi, A.; Kalantari, N.; Nejad, A. M., \& Vardanjani, H. K. (2018). Delineation of groundwater potential zones using remote sensing (RS), geographical information system (GIS), and analytic hierarchy process (AHP) techniques: a case study in the Leylia-Keynow watershed, southwest of Iran. Carbonates and Evaporites, 34(4): 1307-1319.

Mohammed, S. (2017). Groundwater potential mapping using remote sensing and GIS of a part of Chamchamal basin, Sulaimani, Kurdistan Region, Iraq. M.Sc. thesis, University of Miskolc, Miskolc, Hungary.
Oh, H.J.; Kim, Y.S.; Choi, J.K.; Park, E., \& Lee, S. (2011). GIS mapping of regional probabilistic groundwater potential in the area of Pohang City, Korea. Journal of Hydrology, 399(3-4):158-172.

O'Leary, D. W.; Friedman, J. D., \& Pohn, D. A. (1976). Lineament, linear, lineation, some proposed new standards for old terms. Geological Society of America 87: 14631469.

Panahi,M.R.; Mousavi,S.M., \& Rahimzadegan, M. (2017). Delineation of groundwater potential zones using remote sensing, GIS, and AHP technique in Tehran-Karaj plain, Iran. Journal of Environmental Earth Sciences, 76(23): 792.

Ribolzi, O.; Patin, J.; Bresson, L. M.; Latsachack, K. O.; Mouche, E. et al. (2011) Impact of slope gradient on soil surface features and infiltration on steep slopes in Northern Laos. Geomorphology, 127(1-2): 53-63.

Saraf, A.K., \& Choudhury, P.R. (1998). Integrated remote sensing and GIS for groundwater exploration and identification of artificial recharge sites, International Journal of Remote Sensing. Taylor \& Francis, 19(10):1825-1841.

Satty, T. L. (1980). The analytic hierarchy process. McGraw-Hill, New York. 287 Pp.

Shekhar, S., \& Pandey, A.C. (2015) Delineation of groundwater potential zone in hard rock terrain of India using remote sensing, geographical information system (GIS) and analytic hierarchy process (AHP) techniques. Geocarto International 30(4): 402-421.

Sissakian, V. K. (1997). Geological map of Kirkuk Quadrangles, scale 1:250000. State Establishment of Geological Survey and Mining, Iraq-Baghdad. 
Stevanovic, Z. \& Markovic, M. (2004a). Hydrogeology of Northern Iraq.Vol.1, Climate, Hydrology, Geomorphology, and Geology. Food and Agriculture Organization of the United Nations, Rome. Pp. 190

Venkateswaran, S.; Vijay Prabhu, M., \& Karuppannan, S. (2014). Delineation of groundwater potential zones using geophysical and GIS techniques in the Sarabanga Sub Basin, Cauvery River, Tamil $\mathrm{Nadu}$, India. International Journal of Current Research and Academic Review, 2(1): 5875 .

Wattanasen, K., \& Elming, S.A. (2008). Direct and indirect methods for groundwater investigations: a case-study of MRS and VES in the southern part of Sweden. Journal of Applied Geophysics 66(3):104-117.

$\begin{array}{lr}\text { Submitted: } & 09 / 05 / 2020 \\ \text { Revised: } & 28 / 07 / 2020 \\ \text { Accepted: } & 06 / 08 / 2020 \\ \text { DOI: } & 10.48129 / \text { kjs.v48i3.9699 }\end{array}$

